\title{
Risk on financial reporting in the context of the new audit report in Spain
}

\author{
Yolanda Pérez Pérez ${ }^{a}$, María del Mar Camacho Miñano ${ }^{\mathrm{b}}$, María Jesús Segovia-Vargas ${ }^{\mathrm{c}}$ \\ a, b)Departamento de Administración Financiera y Contabilidad, Facultad de Ciencias Económicas y Empresariales, Universidad Complutense de Madrid. Madrid, España. \\ b) Departamento de Economía Financiera y Actuarial y Estadística, Facultad de Ciencias Económicas y Empresariales, Universidad Complutense de Madrid. Madrid, \\ España.
}

\author{
${ }^{a}$ Corresponding author. \\ E-mail address: yolape01@ucm.es
}

\section{A R T I C LE I N F O}

\section{Article history:}

Received 15 February 2019

Received 15 February 2019

Available online 1 January 2021

\section{JEL classification:}

G33
M42

\section{Keywords:}

audit report

listed companies

key audit matters

going concern

emphasis of matter paragraph

qualifications

\section{A B S T R A C T}

After the financial crisis and with the greater complexity of financial reporting, stakeholders asked firms for more informative audit reports to close the audit expectation gap. In this context, the International Auditing and Assurance Standards Board (IAASB) approved a new international standard on auditors reports. One of the major changes is the obligation for listed companies to describe the key audit matters (KAM) in the audit report, in particular, those related to the significant financial reporting risks. This paper empirically analyses the content of the new auditors reports after the accounting reform recently issued in Spain and the factors that condition the KAMs disclosed by auditors. Using the sample of all Spanish listed companies, our results show that these firms mostly report on two to four KAMs and the majority of these relate to revenue recognition, impairment of goodwill and deferred tax recovery in the 2017 audit reports. Applying a multinomial linear regression, the significant variables that condition the KAMs in our sample are sector, market type, and average word count. This evidence contributes to the literature by emphasizing the importance of risks in financial reporting in extended audit reports.

(C)2021 ASEPUC. Published by EDITUM - Universidad de Murcia. This is an open access article under the CC BY-NC-ND license (http://creativecommons.org/licenses/by-nc-nd/4.0/).

Riesgo en la información financiera en el contexto del nuevo informe de auditoría en España

RES U MEN

Tras la crisis financiera y debido a la mayor complejidad de la información financiera, los grupos de interés de las empresas solicitaban un informe de auditoría más completo para reducir el gap de expectativas de la auditoría. En este contexto, el Consejo Internacional de Normas de Auditoría y Aseguramiento (IAASB) aprobó una nueva norma internacional sobre los informes de auditoría. Uno de los principales cambios es la obligación de las empresas que cotizan en bolsa de describir en el informe de auditoría las cuestiones clave de auditoría (KAMs), en particular, las relacionadas con los riesgos significativos de la información financiera. Este artículo analiza empíricamente el contenido del nuevo informe de auditoría tras la reforma contable recientemente aprobada en España y los factores que condicionan los KAMs desglosados por el auditor. Utilizando la totalidad de la muestra de empresas españolas que cotizan en bolsa, nuestros resultados indican que estas firmas presentan en su mayoría entre dos y cuatro KAMs y que casi la totalidad incluyen el reconocimiento de ingresos, el deterioro del fondo de comercio y la recuperación de impuestos diferidos en los informes de auditoría del año 2017. Aplicando una regresión lineal multinomial, las variables significativas que condicionan los KAMs en nuestra muestra son el sector, el tipo de mercado y el número medio de palabras por KAM. Esta evidencia contribuye a la literatura al enfatizar la importancia de los riesgos sobre la información financiera en el informe ampliado de auditoría.

(C)2021 ASEPUC. Publicado por EDITUM - Universidad de Murcia. Este es un artículo Open Access bajo la licencia CC BY-NC-ND (http://creativecommons.org/licenses/by-nc-nd/4.0/). 


\section{Introduction}

After the financial crisis and with growing complexity in financial reporting, investors and other financial statement users have demanded more informative audit reports, and in particular for auditors to provide more relevant information to users (IAASB, 2016). The auditing profession has had to respond to investors around the world who have expressed their dissatisfaction over audit reports. A simple 'true and fair' opinion is no longer enough and they ask for more informative reports. This is called the "audit expectation gap" and it has been extensively analyzed in the previous literature, leading to the enhancement of the role of the new standards in achieving more effective financial reporting for the decision-making process of its users. In this context, the International Auditing and Assurance Standards Board (IAASB), aware of the need for change in the focus of audit reports, approved a new international standard that incorporates major changes in the information contained in audit reports (IFAC, 2013). One of the major changes is the obligation for listed companies to describe in the audit report the key audit matters (KAMs) and the audit work performed in relation to those issues (KPMG, 2017).

In the European Union, the IAASB regulatory framework has been adopted through Directive 2014/56/EU and EU Regulation No. 537/2014 (of the European Parliament and of the Council, 2014). In Spain, as a first step in the process for the adoption of the European regulations, the Account Auditing Law 22/2015 (LAC for its Spanish initials) was published in July 2015 and applied to the financial years starting from June 17, 2016. This new audit law introduces profound changes in audit reports compared to the previous requirements, in line with the new approach of the International Standards on Auditing (ISA) and taking into account the local audit market in Spain, characterized by a high concentration in the Big Four audit companies, especially for performing audits of the big companies such as listed companies, public interest companies, multinationals, etc. (ICAC, 2017) with a high level of competition failing to emerge due to the high entry barriers (Ruiz Barbadillo, Rodríguez Castro, \& Biedma López, 2016).

Taking into account all these regulatory changes, this paper empirically analyses the content of the new audit reports after the accounting reform recently introduced in Spain. Specifically, the aim of this analysis is twofold: to analyze the content of the extended audit reports, especially focused on KAMs, and to evaluate what factors condition those KAMs. Regarding the first objective, we have classified the audit reports into three categories based on (i) the audit qualification, going concern and emphasis of matter sections; (ii) KAMs associated with accounting headings in the financial statements and (iii) general KAMs. For the second objective, some factors have been considered such as sector, market type, auditor size, audit opinion, the existence of the emphasis paragraph, going concern paragraph and the average word count per KAM.

We have manually created a final sample of 131 listed firms by compiling financial and audit information from two data sources: the $\mathrm{CNMV}^{1}$ website has provided the audit reports and the ICJCE ${ }^{2}$ database was used for the classification of the KAMs. The main contribution of this paper is to be the first, to the best of our knowledge, to analyze the

\footnotetext{
${ }^{1}$ The stock market regulator, the Spanish National Securities Market Commission

${ }^{2}$ The Instituto de Censores Jurados de Cuentas de España (ICJCE) is the most important Spanish Auditors' associations.
}

content of the extended audit reports, with a special focus on KAMs, of the listed firms in Spain after the audit reform. Other contributions involve the interconnection between the risk in financial reporting and auditing, and it is an extension of Muñoz-Izquierdo, Camacho-Miñano, \& PascualEzama (2017)'s study but with the new audit regulation instead of the previous regulation of the audit report. Prior research on the effects of expanded audit reports has mainly been conducted in Anglo-Saxon countries and there is a lack of research on continental European countries. Therefore, our study aims to extend the literature examining the value of audit reports and to provide information for ongoing regulatory actions. For instance, auditors in the US will start issuing expanded reports in 2019, including a discussion of critical audit matters ${ }^{3}$ (CAMs). We hope that our study can motivate discussion of additional mechanisms for improving the content of reports in Spain and in other jurisdictions. Additionally, regulators, analysts, auditors, managers, and investors could benefit from the results of this study, which presents an in-depth analysis of the risks in financial reporting through the audit report after the IAASB's reforms and, therefore, key information for making better business decisions and enhancing the relevance of auditing.

The remainder of this paper is organized as follows. Section 2 examines the theoretical framework and the key changes to audit reports after the audit reform. Section 3 presents academic research related to extended audit reports through a review of the literature. Section 4 describes the sample and the method used to analyze the extended audit reports. Section 5 contains the results and a discussion of this analysis. Finally, some conclusions are presented in Section 6.

\section{Theoretical framework: audit expectation gap and the new audit regulatory framework}

The new audit regulatory framework is designed to address the gap between society's expectations of auditors and their actual performance, as perceived by society. There is extensive literature focused on analyzing the causes of the expectation gap, proposing different alternatives to minimize it and giving the results of some of these. Different frameworks have been described in the literature to identify the causes of the audit expectation gap. One of the most cited is by Porter (1993) who explains the structure of the audit expectationperformance gap based on two components: the reasonableness gap and the performance gap (deficient standards and deficient performance). According to the results of his study, deficient standards is the component of the model with the greatest impact on the total audit expectation gap. Applying Porter's model, Masoud (2017) empirically examined the causes of the audit expectation gap in Libya and reached similar results to Porter.

Different measures to narrow the audit expectation gap have been identified, either by lowering the public's expectations or by improving audit performance (Chye Koh et al., 1998; Gonzalo Angulo \& Garvey, 2018). These measures can be grouped under three main headings: increased awareness of audit responsibilities, greater auditor independence, and improved auditor reporting models. Regarding the first aspect, Salehi (2011) performed an extensive literature review of the audit expectation gap and concluded that this gap should be reduced by auditors, improving audit respons-

\footnotetext{
${ }^{3}$ The Critical Audit Matters (CAMs) are used in the American regulation for the Key Audit Matters (KAMs) in Europe.
} 
ibilities, educating different users and demanding new standards. In this line, Adeyemi and Marte Uadiale (2011) suggest educating the public about the objectives of an audit and the auditor's role and responsibilities. Regarding the second aspect, Ruhnke and Schmidt (2014) proposed changes, such as mandatory rotation and a prohibition on non-audit services, which could reduce the gap but only to a smaller extent. In this area, Toumeh et al. (2018) recommend strengthening the independence of auditors and enhancing the powers of the Association of Certified Public Accountants in its supervisory role. Finally, regarding the third aspect, Vanstraelen, Schelleman, Meuwissen, and Hofmann (2012) developed an alternative audit reporting model that could significantly reduce the information gap between users and auditors and improve transparency about the quality of audits. RatzingerSakel and Gray (2015) also proposed improvements to the auditor reporting model, specifically the inclusion of a more narrative-based report in areas such as estimates, judgments, the sufficiency of evidence and uncertainties and the auditor's role and limitations in detecting fraud.

However, the results of these potential mechanisms may not imply success in reducing this gap. Ruiz Barbadillo (1998) performed an analysis of empirical research and resolved that the informative value of the audit report has been questioned during at least three decades. A study by Gold, Gronewold, and Pott (2012) concluded that explaining the ISA 700 auditor's report does not result in a smaller expectation gap and that the audit opinion alone may signal sufficient relevant information to users. Litjens, Buuren, and Vergoossen (2015) observed that changes to the format of audit reports do not really reduce the audit expectation gap of bankers. In the same line, some previous research (Quick \& Schmidt, 2018; Samsonova-Taddei \& Humphrey, 2015) found that regulatory measures taken or supported by the European Commission had no positive impact on the perceptions of auditor independence and audit quality. This may be because the policy preferences of individual EU Member States have a substantial influence on the outputs of European audit policymaking. A recent study also states that investors recognize that there is a significant gap between the financial information used for their decision-making process and its effectiveness due to factors such as the lack of sufficient detail in qualitative information (PWC, 2019, MartínezBlasco, Vivas-Crisol, \& Garcia-Blandon, 2019).

Current and recent audit reforms taking place internationally aim to meet the needs of audit report users by reducing the expectation gap, providing more relevant information on the audit (IAASB, 2015). The new audit report will provide more information than the existing one. The AICPA Auditing Standards Board (ASB) and the IAASB carried out research to identify and provide information and insights into the nature of user perceptions regarding the auditing of financial statements and audit reports. This included various types of financial statement and audit report users. The result of their research is that there is little evidence that the information provided in current audit reports is taken into account in the decision-making of users and that additional disclosures and communications are required in the audit reporting process (Mock, Gray, Coram, \& Turner, 2009).

The value of independent audit reports to society has been questioned for many years. This concern arises due to the fact that, despite the audit work of independent auditors, the users of these reports do not see them as a reliable source of information due to the many corporate scandals taking place in the capital markets (Sikka, 2009). Historically, audit reports have been described as a boilerplate pass/fail model because the auditor issues either an unqualified (pass) or qualified (fail) opinion, with both opinions containing largely standardized wording. Most regulators and stock exchanges require companies to receive unqualified opinions, which results in nearly all publicly traded companies receiving essentially the same unqualified audit report (Butler, Leone, \& Willenborg, 2004; Czerney, Schmidt, \& Thompson, 2014; Lennox, Wu, \& Zhang, 2015). Investors have said that these standardized audit reports convey little company-specific information and that auditors possess private information that might be useful to them if disclosed (Public Company Accounting Oversight Board-PCAOB-, 2013).

As a result of this reform process, which ended with the issuance and publication of various standards (among the most relevant being the new ISA 701 "Communicating Key Audit Matters in the Independent Auditor's Report"), the auditors who perform audits in accordance with the ISA will be obliged, among other aspects, to describe in the auditor's report for listed companies the KAMs and the audit work carried out in relation to these issues. The effective date for its introduction was for financial years ending on December 15, 2016. In general, most EU countries will apply the new requirements in the financial years ending in 2017. Other countries, such as Australia, the UK, and the Netherlands, have already made the transition and the response from stakeholders has been very positive (KPMG, 2016). In the European Union, the IAASB regulatory framework has been adopted through the aforementioned Directive 2014/56/EU and Regulation No. 537/2014).

The current IAASB auditor's report reforms include enhancements to its content and structure. The new auditor's report includes seven sections: opinion, the basis for the opinion, going concern, KAMs, other information, management's responsibility, and auditor's responsibility. The opinion content is unchanged but the text is moved from the end of the report to the beginning. The basis for the opinion section includes a statement on the auditor's independence. Any material uncertainty relating to the firm's ability to continue as a going concern is described in a separate section. The KAMs (described as areas where there might be a higher risk of material misstatement or those where significant management or auditor judgments are involved, including accounting estimates) are described in a new section including a reference to the related disclosure(s), if any, in the financial statements, why the matter was determined to be a KAM and how the matter was addressed in the audit. Other information constitutes a new section, detailing the auditor's responsibility for other information that accompanies the financial statements and the result of the procedures applied to it. Management's responsibility is expanded to include an explanation of the management's responsibilities with respect to the going concern principle and the auditor's responsibility section includes a more comprehensive description of the auditor's responsibilities, including with respect to the going concern principle.

\section{Background and Research Questions}

As mentioned in the previous section, the new audit report is an important way to reduce the audit expectation gap. Specifically, dealing with the gap caused by deficient standards has been the key objective of the aforementioned audit reforms. Consequently, it is necessary to analyze existing studies on the new audit report. To achieve our objective, we have carried out a systematic literature review based on an analysis of existing academic articles. This has been 
Table 1

Literature review of risk on financial reporting and auditing

\begin{tabular}{|c|c|c|c|c|c|}
\hline $\begin{array}{l}\text { Research } \\
\text { Area }\end{array}$ & Authors & Objectives & Key findings & Methodology & $\begin{array}{l}\text { Sample (country/ type of } \\
\text { firms/ years / number) }\end{array}$ \\
\hline \multirow{8}{*}{$\begin{array}{l}\text { 1. Impact } \\
\text { of the } \\
\text { new audit } \\
\text { reform }\end{array}$} & $\begin{array}{l}\text { Guiral- } \\
\text { Contreras et al. } \\
\text { (2007) }\end{array}$ & $\begin{array}{l}\text { To examine the significance of the audit } \\
\text { report in loan rating decisions. }\end{array}$ & $\begin{array}{l}\text { The qualified audit report appears to be an independent and useful piece of } \\
\text { evidence when it is contrary to favourable financial expectations. }\end{array}$ & Questionnaires & $\mathrm{n} / \mathrm{a}$ \\
\hline & $\begin{array}{l}\text { Gassen \& Skaife } \\
(2009)\end{array}$ & $\begin{array}{l}\text { To investigate the audit market effects of } \\
\text { audit reforms mandated by the German } \\
\text { government. }\end{array}$ & $\begin{array}{l}\text { The audit reforms improved the information role of German audits and German } \\
\text { firms responded to the improvement in audit reporting by increasing their } \\
\text { demand for dominant audit suppliers. }\end{array}$ & $\begin{array}{l}\text { Logistic } \\
\text { regression }\end{array}$ & $\begin{array}{l}\text { Germany/ publicly traded } \\
\text { /1996, 1997, } 1999 \text { and } \\
\text { 2000/46 firm-year } \\
\text { observations }\end{array}$ \\
\hline & $\begin{array}{l}\text { Coram et al. } \\
\text { (2011) }\end{array}$ & $\begin{array}{l}\text { To evaluate to what extent is an unqualified } \\
\text { auditor's report attended to by analysts in } \\
\text { undertaking a company valuation and if the } \\
\text { assessments of the auditor's report are } \\
\text { positive or negative. }\end{array}$ & $\begin{array}{l}\text { Professional financial analysts pay little attention to the content of an unqualified } \\
\text { auditor's report, which suggested the lack of further processing is due to the audit } \\
\text { report being 'boilerplate' }\end{array}$ & Questionnaires & $\begin{array}{l}\text { Australia/n.d/16 } \\
\text { Australian professional } \\
\text { financial analysts }\end{array}$ \\
\hline & Carson et al. & $\begin{array}{l}\text { To synthesize and discuss prior academic } \\
\text { literature pertinent to the auditor's decision } \\
\text { to issue a going concern (GCO). }\end{array}$ & $\begin{array}{l}\text { There are three major areas of research: determinants of GCOs that include client } \\
\text { factors, auditor factors, auditor-client relationships, and other environmental } \\
\text { factors; the accuracy of GCOs; and the consequences arising from GCOs. }\end{array}$ & $\begin{array}{l}\text { Literature } \\
\text { review }\end{array}$ & $\begin{array}{l}\text { US/ publicly traded } \\
\text { /2000-2010/88,359 } \\
\text { company year observations }\end{array}$ \\
\hline & $\begin{array}{l}\text { Zenzerovic \& } \\
\text { Valic-Vale } \\
\text { (2016) }\end{array}$ & $\begin{array}{l}\text { To test if the going concern paragraph } \\
\text { included in the audit report is an indicator of } \\
\text { financial difficulties for a company. }\end{array}$ & $\begin{array}{l}\text { An auditor's report accompanied by an explanatory paragraph pointing out issues } \\
\text { f associated with the GCO is the proper criterion for differentiating companies } \\
\text { experiencing financial difficulties. }\end{array}$ & $\begin{array}{l}\text { Logistic } \\
\text { regression }\end{array}$ & $\begin{array}{l}\text { Zagreb/ publicly traded } \\
\text { /2009/191 companies } \\
\text { from the nonfinancial } \\
\text { sector }\end{array}$ \\
\hline & $\begin{array}{l}\text { Tahinakis \& } \\
\text { Samarinas } \\
(2016)\end{array}$ & $\begin{array}{l}\text { To examine the incremental information } \\
\text { content of audit opinion while considering } \\
\text { opinion determinants, such as auditor and } \\
\text { auditee size, or a firm's financial state. }\end{array}$ & $\begin{array}{l}\text { Audit opinion has a significant market impact. The estimated positive or negative } \\
\text { information content of the audit opinion types is associated with certain opinion } \\
\text { determinants, such as auditor and auditee size and a firm's financial state. }\end{array}$ & $\begin{array}{l}\text { Logistic } \\
\text { regression }\end{array}$ & $\begin{array}{l}\text { US/ firm data collected } \\
\text { over } 30 \text { years }\end{array}$ \\
\hline & $\begin{array}{l}\text { Abad et al. } \\
(2017)\end{array}$ & $\begin{array}{l}\text { To analyze the relationship between the } \\
\text { content of the audit reports and information } \\
\text { asymmetry levels in the stock market for a } \\
\text { sample of Spanish firms. }\end{array}$ & $\begin{array}{l}\text { Audit qualifications are associated with higher levels of information asymmetry. } \\
\text { Audit reports issued by Big } 4 \text { auditors are associated with lower levels of } \\
\text { information asymmetry in the market. Bigger and healthier firms show less } \\
\text { probability of receiving qualified opinions. }\end{array}$ & $\begin{array}{l}\text { Regression } \\
\text { model }\end{array}$ & $\begin{array}{l}\text { US/ publicly traded } \\
\text { /2001-2008/103 firms and } \\
562 \text { firm-year observations }\end{array}$ \\
\hline & $\begin{array}{l}\text { Prasad \& Char } \\
(2017)\end{array}$ & $\begin{array}{l}\text { To examine the current audit report reforms } \\
\text { and their implications, in particular, the } \\
\text { perceptions of prominent stakeholders in } \\
\text { respect of the informational value of the } \\
\text { audit report, audit quality and audit costs. }\end{array}$ & $\begin{array}{l}\text { The changes to the audit report are of significant informational value to users, } \\
\text { while the implications for audit quality are unclear. Indeed, the changes would } \\
\text { increase audit costs and potentially the legal liability of auditors. }\end{array}$ & $\begin{array}{l}\text { Literature } \\
\text { review }\end{array}$ & $\mathrm{n} / \mathrm{a}$ \\
\hline \multirow{4}{*}{$\begin{array}{l}2 . \\
\text { Extended } \\
\text { audit } \\
\text { report } \\
\text { analysis }\end{array}$} & $\begin{array}{l}\text { Manoel \& Quel } \\
\text { (2017) }\end{array}$ & $\begin{array}{l}\text { To study the main changes in innovating the } \\
\text { new independent audit report aiming to } \\
\text { close the users of the financial reporting } \\
\text { expectation gap. }\end{array}$ & $\begin{array}{l}\text { The stakeholders may use KAMs in their process of analysis and decision-making. } \\
\text { The new auditor's report is contributing not only to the quality of the audit } \\
\text { engagements but also to improve the information expected by the public in } \\
\text { general, thus responding to the user's expectation gap }\end{array}$ & $\begin{array}{l}\text { Literature } \\
\text { review }\end{array}$ & $\mathrm{n} / \mathrm{a}$ \\
\hline & $\begin{array}{l}\text { Christensen et } \\
\text { al. (2012) }\end{array}$ & $\begin{array}{l}\text { To examine estimates reported by public } \\
\text { companies. } \\
\text { To set forth several modest steps that would }\end{array}$ & $\begin{array}{l}\text { Changes in the estimates often impact on net income; consequently, the extreme } \\
\text { estimation uncertainty also resides in measures such as earnings per share. } \\
\text { Specific areas addressed are: the auditor's engagement in evaluating }\end{array}$ & $\begin{array}{l}\text { Literature } \\
\text { review }\end{array}$ & $\mathrm{n} / \mathrm{a}$ \\
\hline & Cox (2013) & $\begin{array}{l}\text { enhance the overall quality of financial } \\
\text { reporting by discretely tinkering with the } \\
\text { outside auditor's opinion that accompanies } \\
\text { the financial statements. }\end{array}$ & $\begin{array}{l}\text { management's assessment of internal controls; the duration of the auditor's } \\
\text { relationship with the audit client; whether the auditor concurs in management's } \\
\text { assessment of the critical estimates, judgments, and assumptions; and the } \\
\text { auditor's assessment of whether the firm is experiencing financial distress. }\end{array}$ & $\begin{array}{l}\text { Literature } \\
\text { review }\end{array}$ & $\mathrm{n} / \mathrm{a}$ \\
\hline & $\begin{array}{l}\text { Hategan et al. } \\
\text { (2015) }\end{array}$ & $\begin{array}{l}\text { To test if the current form and content of the } \\
\text { auditor's report are in accordance with the } \\
\text { current needs and requirements of the users. }\end{array}$ & $\begin{array}{l}\text { There are differences in perspectives and expectations between the financial } \\
\text { auditors, the chief financial officers of the audited companies and the users of the } \\
\text { audited accounting information regarding the auditor's report. }\end{array}$ & $\begin{array}{l}\text { Questionnaires } \\
\text { and non- } \\
\text { parametric tests } \\
\text { of Kruskal } \\
\text { Wallis and } \\
\text { Mann Whitney }\end{array}$ & $\begin{array}{l}\text { Romania/audited } \\
\text { companies/2012- } \\
2014 / 600 \text { auditors from } \\
\text { Romania and } 1000 \text { from } \\
\text { Spain }\end{array}$ \\
\hline
\end{tabular}

To synthesize the extant literature in Neuro$\begin{array}{lll}\text { Fisher et al. } & \text { Linguistic Programming (NLP) in } & \text { NLP applications have been used to mine financial and audit documents to obtain } \\ \text { accounting, auditing, and finance to } & \text { insights, make inferences and to create additional methodologies and artifacts to }\end{array}$ establish the state of current knowledge and advance knowledge in accounting, auditing, and finance. to identify paths for future research.

The audit report must be readable by all users of the financial statements.

To analyze the structure and linguistic Comprehensibility of the report is a qualitative feature that enhances the

Fakhfakh features of consolidated audit reports that illustrated according to the ISA 700 .

usefulness of financial information. The linguistic imperfection of international accounting standardization can reduce the relevance and reliability of the audit report.

Audit reports are not readable by all users of the financial statements. The same The study results confirm the significant impact of specific determinants on the readability of sample of 42

Fakhfakh To analyze the linguistic features and (2016b) readability of auditors' reports on consolidated financial statements in Tunisia.

To investigate the impact of expanded audit reports, the assurance level, materiality levels, and KAMs, on bank director

$\begin{array}{ll}\text { Boolaky \& } & \text { perceptions of the quality of the financial } \\ \text { Quick (2016) } & \text { statements, the audit procedure, and the }\end{array}$ audit report, as well as on their credit approval decision. To provide experimental evidence that

disclosing CAMs is unlikely to increase and in certain circumstances, could decrease auditors' litigation risk in the event that an audit fails to detect a material misstatement To investigate whether the regulatory

change in the expanded auditor's report was No evidence that the regulatory change affected significantly investors' reaction to
Gutierrez et al. associated with an increase in the decision (2017) al a d a release of auditors' reports, audit fees, or audit quality. Also, variation in the usefulness of the auditor's report and also if on audit fees and audit quality.

Matters

(KAM) To investigate the effect of communicating

Sirois et al. KAMs in the auditor's report on users' information acquisition when analyzing financial statements. audit reports such as modification of the opinion of the independent auditor and the audit report lag.

Disclosing the assurance level has a significantly positive impact on bank director perceptions of the quality of the financial statements.

ANOVAs, OLS

audit reports

CAM disclosures could be particularly helpful in reducing litigation risk stemming from seemingly simple accounts that pose idiosyncratic audit challenges for certain clients.

Questionnaires n/a regressions and Tobit

US/n.d/105 regressions bank directors To examine the effects of CAMs disclosure Steven et al. in the auditor's report on auditor legal exposure.

expanded reports' content had a negligible effect on these outcomes.

To investigate whether the introduction of

$\begin{array}{ll}\text { Clive et al. } & \text { an expanded audit reporting model in the } \\ \text { (2019) } & \text { U.K. conveys useful incremental information }\end{array}$ to investors.

Participants access KAM-related disclosures more rapidly and pay relatively more attention to them when KAMs are communicated in the auditor's report. However, when exposed to an auditor's report with several KAMs, participants devote less attention to the remaining parts of the financial statements.

Instead of increasing legal exposure as audit practitioners have feared, CAM disclosures could actually mitigate auditor legal exposure.

The disclosures lack incremental information content because most of the risks had been already disclosed by management in the earning's announcement, in the expanded audit reports.

informed about a majority of the risks before the risks were disclosed by auditors Gambetta et al. in the audit reports in Spain, distinguishing Spain and in the United Kingdom, the differences in the number of KAMs are not (2019) if these KAMs are an entity-level or account- been relevan level risk after the experience in the UK

Questionnaires n/a

Questionnaires n/a

\section{Regression UK/2013/488} companies

UK/2013-2016/ 144 observations of non financial companies listed in the FTSE100 
performed in a rigorous manner as justified, for example, by Tranfield et al. (2003). The main research database, "Web of Science", gave 108 results when we searched for, "audit report content", as the "Topic", as of February 15, 2019. After a thorough review of all the articles, we excluded 94 papers because their main focus was on different aspects of the audit, not specifically the audit report. We, therefore, had the remaining 14 articles for our study. As we wanted to identify any articles related to the extended audit report resulting from the recent audit reform, additional research was performed using the same filters but searching for "extended audit report" as the "Topic". As a result of this, eight additional papers have been included in our literature review. In order to systematize and organize the literature, we decide to categorize the papers according to their main subject matter using three areas of research: the impact of the new global audit reform, audit report analysis and extended audit reports. A list of all the reviewed articles appears in Table 1, together with the areas of research and details of each study.

The literature review provides two important insights: (i) audit reform can enhance the communicative value of the auditor's report for users of financial reporting, especially through the description of KAMs; and (ii) the extended audit report should help users to focus on matters that are likely to be important in their decision-making process. In this context, and as previously mentioned, the main objectives of this study are to analyze the content of the extended audit report, especially focused on KAMs, and to evaluate whether they are conditioned by several features of the firms. Therefore, in line with the audit expectation gap framework, we formulate the following research questions:

Research Question 1 (RQ1): What type of content is provided in the new extended audit report in Spain?

Research Question 2 (RQ2): What is the relationship between the content of the KAMs and the structural factors: (i) company sector; (ii) market type; (iii) auditor size, (iv) audit opinion, (v) the existence of the emphasis paragraph, (vi) going concern and (vii) average word count per KAM?.

We consider that this work can complement the existing literature because, to the best of our knowledge, it is the first study to analyze KAMs as part of the audit report in Spain. Additionally, we think that regulators, auditors, investors, and lenders could benefit from the results of this study since it contains evidence about how informative the report is after the IAASB reform.

\section{Sample and Methodology}

\subsection{Sample}

Our initial sample consisted of all firms on the main Stock Exchange market in Spain as of December 2017. For this purpose, we have used the Orbis database which gave 253 results when we searched for "Listed Firm" in "Spain" as of November 10, 2017. From the total, we have excluded the firms listed on the Mercado Alternativo Bursátil (MAB) because this market has some particular features ${ }^{4}$ and conditions (see Table 2).

The final sample by market type is 35 firms (27\% of the sample) from the IBEX 35 and 96 firms (73\% of the sample) from the Continuous Market (CM).

\footnotetext{
${ }^{4} \mathrm{MAB}$ has a tailor-made regulation and costs and processes specifically designed for the listed companies.
}

Table 2

Breakdown of the sample by type of market

\begin{tabular}{lcl}
\hline Type or market & Number of Firms & Comments \\
\hline IBEX-35 & 35 & \\
CM & 109 & \\
MAB & 109 & \\
Initial Sample & 253 & From the total, we have excluded: \\
- MAB & -109 & Firms listed in the MAB because they have some \\
- Restructuring/dissolution companies & -2 & Pescanova and Amci Habitat, S.A \\
- Company transfer to Euronex & -1 & Quadpack Industries, S.A. \\
- Company nonapplicable UE Reform & -2 & Borges (closed at 31 May); Adolfo Dominguez (closed at \\
in 2017 & -4 & 31 February) \\
- Companies in dissolution process & -4 & and Unión Catalana Cartera Industrial Rea, S.A, Ronsa, S.A \\
- Companies without consolidated & -4 & Biosearch, S.A, Bodegas Bilbainas, S.A, Oryzon \\
$\quad$ financial statements & 131 & \\
Final Sample & & \\
\hline
\end{tabular}

Source: own elaboration based on the Orbis database and the classification of Bolsa de Madrid (http://www.bolsamadrid.es/esp/aspx/Empresas/Empresas.aspx).

\subsection{Methodology}

For the first research question, our methodology consists of the reading, analysis, and classification of the content of the new audit reports of the 131 listed companies. This content includes the sections on opinion, going concern (if applicable) and emphasis of matter (if applicable), as well as the KAMs. For every firm, we extracted their financial statements, including the extended audit report, from the CNMV for the fiscal year ending on December 31, 2017.

We identified the KAMs and classified them according to their nature on the basis of the criteria established by the ICJCE (Spanish Institute of Chartered Accountants). We have split these KAMs into two categories: accounting KAMs, which relate to a specific heading in the annual accounts; and general KAMs, which relate to more general issues, somewhat conditioned by external factors. As the number of KAMs classified by the ICJCE amounted to 23, the analysis became more complex and the results more difficult to understand. Based on professional audit judgement and taking into account the current audit regulations, these 23 KAM have been grouped into ten (see Table 3):(1) Fixed assets includes fixed assets and investment property, intangible assets, financial investments, and investments in group companies and associates; (2) Current assets include inventory and other current assets; (3) Liabilities includes debts with credit institutions, pensions, other financial liabilities, provisions, and contingent liabilities; (4) Revenue recognition; (5) Goodwill and Business Combinations; (6) Taxes also includes deferred taxes; (7) Legal and Regulatory Compliance including control terms compliance; (8) Related Party Transactions; (9) Going concern and (10) Information Systems.

For the classification, a category is created for each KAM that appears in the report and the KAM is given the value 1. The rest of the categories not appearing in the report are assigned the value 0 , thus creating dichotomous variables. This process generates variables including both the type of opinion and the KAMs reported. In this way, we transform the qualitative nature of audit reports into a set of quantitative or dichotomous variables for subsequent statistical analysis to answer the first question in the study. The categories or variables included in the classification are detailed in section 5.1.1.

Additionally, for the second research question, we use cross-tabulation or contingency tables to examine the direct relationship between the content of the audit report and each of the seven selected structural factors mentioned above. The contingency tables show the joint frequencies of the levels taken by the variables. The statistical significance of the differences between these levels is evaluated using the Pearson Chi-square test $\left(\mathrm{X}^{2}\right)$, which verifies the relationships of in- 
dependence or association between variables. At the $95 \%$ statistical significance level ( $p$-value $<0.05$ ), we do not accept the hypothesis of independence of the content of the audit report and each of the seven structural factors studied. Given a large number of columns and rows, the low number of observations, and the subsequent low number of counts in many cells (frequently zero counts) in the different tables in the paper, some statistical corrections have been applied, specifically the Fisher-Freman-Halton and G- tests. For the average word count per KAM, as a non-categorical variable, we use a non-parametric test for two independent samples. The significance level is also 95\%.

Regarding the classification of the sector, we have grouped this into eight categories based on the National Classification of Economic Activities (NACE-2009): construction and real estate, consumption and distribution, energy and natural resources, financial, health, industry, services and technology, media and communications.

The market type the firm belongs to can be the IBEX-35 or the CM.

For auditor size, using the criteria used in the previous study by Boone et al. (2010), we have distributed the sample identifying four categories: 'Big4' or the four large international audit firms, which includes Deloitte, EY, KPMG and PwC; 'Second-tier' or medium-sized firms, in which we have BDO Auditores, S.L. and Grant Thornton, S.L.P.; 'rest corporations' or other small auditing firms in the form of mercantile companies; and individual, including sole auditors or individuals who provide audit services.

For the type of audit opinion, there are two options: unqualified, when the auditor's opinion of the annual accounts is that they are free from material errors; and qualified, when the auditors add some qualifications to their audit reports.

And if the company has an emphasis or going concern section, the value of each variable will be 1 , and 0 otherwise.

The mean of the average word count per KAM is 410.22 words with a standard deviation of 147.51 words. We calculate this directly from copying and pasting the audit report into a Word file. The minimum number of words is 116 and the maximum is 1,198 .

Additionally, we ran a multinomial regression model to test the significance of the different KAMs related to the seven factors considered. Several validity measures are used to ensure the robustness of our model.

\section{Results and discussion}

Our observations are based on the analysis of the auditor's reports issued by auditors in Spain included in the first set of annual reports of entities listed on the main Stock Exchange in Spain ("Ibex-35" and CM) after the enhanced auditor reporting standards became effective (that is, for the financial statements as of December 31, 2017). A total of 131 auditor's reports, including 373 KAMs in total, were reviewed as part of the study.

We have divided the results into two parts, each relating to one of our two research questions: 1) the analysis of the content of the extended audit report and 2) the analysis of the content of the extended audit report given the structural factors.

\subsection{Analysis of the content of the extended audit report}

\subsubsection{Frequency of the content of the audit report}

The frequency and representativeness of each item of the classification is shown in Table 3 in order to answer the first research question.

Table 3

The frequency of the content of the audit report

\begin{tabular}{|c|c|c|c|c|}
\hline Abbreviation & Explanation & Frequency & $\%$ Block & \% Sample (131) \\
\hline \multicolumn{5}{|c|}{ Block A: Type of paragraph } \\
\hline AUOPI & Audit Opinion & 3 & $16 \%$ & $2 \%$ \\
\hline EMPHA & Emphasis of matter & 4 & $21 \%$ & $3 \%$ \\
\hline GCPHA & Going concern & 12 & $63 \%$ & $9 \%$ \\
\hline \multicolumn{5}{|c|}{ Block B: Accounting KAM (ACCKAM) } \\
\hline FIXA & Fixed Assets & 77 & $21 \%$ & $59 \%$ \\
\hline CURA & Current Assets & 27 & $7 \%$ & $21 \%$ \\
\hline LIAB & Liabilities & 56 & $15 \%$ & $43 \%$ \\
\hline REV & Revenue recognition & 58 & $16 \%$ & $44 \%$ \\
\hline GBC & Goodwill and Business Combinations & 70 & $19 \%$ & $53 \%$ \\
\hline $\mathrm{TAX}$ & Taxes & 52 & $14 \%$ & $40 \%$ \\
\hline \multicolumn{5}{|c|}{ Block C: General KAM (GRALKAM) } \\
\hline LRC & Legal and regulatory compliance & 10 & $3 \%$ & $8 \%$ \\
\hline RPT & Related Party transactions & 8 & $2 \%$ & $6 \%$ \\
\hline GC & Going concern & 4 & $1 \%$ & $3 \%$ \\
\hline ISY & Information systems & 11 & $3 \%$ & $8 \%$ \\
\hline
\end{tabular}

Source: Own elaboration.

In the following sections, a specific analysis is performed to show the results of each block.

\subsubsection{Type of paragraph (Block $A)$}

\subsubsection{Type of opinion}

Only three qualified opinions given by auditors in 2017 were identified. One is related to Dogi International Fabrics, SA, audited by PWC, due to tax contingencies associated with some subsidiaries and non-provisions recorded. Another qualified opinion is for Compañía Levantina de Edificación y Obras Públicas, S.A, audited by an individual auditor (Mr. Luis Caruana), due to uncertainty related to the bankruptcy of a significant subsidiary. The final one is for Mobiliaria Monesa, S.A, audited by BDO, in relation to it being of limited scope in relation to a significant subsidiary due to the lack of financial reporting for that subsidiary. The rest of the auditors' opinions are unqualified, which means that the listed companies' financial statements broadly give a true and fair view of their economic and financial situations.

\subsubsection{Emphasis of matter paragraph}

As Spanish experience of such reporting relates to the largest companies, qualified opinions and emphasis of matter paragraphs are rare. The reports follow the requirements of the relevant ISAs which may preclude reporting KAMs in certain circumstances. Therefore, a total of only four emphasis of matter paragraphs by auditors in 2017 were identified, considering both IBEX-35 and CM. The four cases are as follows: Ferrovial S.A. (construction company) in the IBEX-35 (audited by Deloitte) for the application of IFRIC 15 "Agreements for the Construction of Real Estate in anticipation"; Unicaja Banca S.A. (financial company) in the CM (audited by PWC) due to its merger; Amper S.A. (technology company) in the CM (audited by EY) for its agreement for the sale of the Pacifico Sur business subject to some conditions and licenses; and finally, Mobiliaria Monesa S.A. (real estate company) in the CM (audited by BDO) for uncertainty related to the bankruptcy of a significant subsidiary.

\subsubsection{Going concern}

Only 12 going concern paragraphs by auditors in 2017 were identified. Three of these refer to companies given a qualified opinion (see Block A, Table 4).

It is remarkable that some auditors deal with the going concern issue as a KAM rather than as a specific section (see Block B, Table 5). This issue is interesting because when the 
Table 4

Going concern information in the extended audit report

\begin{tabular}{|c|c|c|c|c|}
\hline Auditor & Market & Company & Sector & Going concern \\
\hline \multicolumn{5}{|c|}{ Block A: Going concern paragraphs } \\
\hline PWC & CM & Dogi International Fabrics, S.A & Services & negative equity; negative working capital \\
\hline Luis Caruana & $\mathrm{CM}$ & $\begin{array}{l}\text { Compañía Levantina de Edificación } \\
\text { y Obras Públicas, S.A }\end{array}$ & Construction & negative equity; negative working capital \\
\hline $\mathrm{BDO}$ & $\mathrm{CM}$ & Mobiliaria Monesa, S.A & Real Estate & Significant losses in a signficant subsidiary \\
\hline Deloitte & $\mathrm{CM}$ & Obrascon Huarte Lain, S.A & Construction and Real Estate & $\begin{array}{l}\text { Financing associated to the compliance of } \\
\text { desinvestments }\end{array}$ \\
\hline Deloitte & $\mathrm{CM}$ & Abengoa, S.A & Energy and natural resources & Negative equity \\
\hline EY & CM & Duro Felguera, S.A & Construction and Real Estate & negative equity, negative working capital \\
\hline PWC & CM & Tubos Reunidos, S.A & Industry & negative equity; negative working capital \\
\hline Deloitte & $\mathrm{CM}$ & $\begin{array}{l}\text { Corporación Empresarial de } \\
\text { Materiales de Construcción, S.A }\end{array}$ & Consumption and distribution & $\begin{array}{l}\text { Desinvestment in a company which is the } \\
\text { principal source of revenues and some } \\
\text { contingencies }\end{array}$ \\
\hline $\begin{array}{l}\text { Baker Tilly } \\
\text { Fmac, SLP }\end{array}$ & $\mathrm{CM}$ & Urbas Grupo Financiero, S.A & Services & $\begin{array}{l}\text { Negative working capital; uncertainty over } \\
\text { novation of financing agreements }\end{array}$ \\
\hline $\mathrm{BDO}$ & CM & Urbar Ingenieros, S.A & Construction and real estate & $\begin{array}{l}\text { Negative working capital; uncertainty over } \\
\text { novation of financing agreements }\end{array}$ \\
\hline $\begin{array}{l}\text { HORWATH } \\
\text { AUDITORES } \\
\text { ESPAÑA S.L. }\end{array}$ & $\mathrm{CM}$ & $\begin{array}{l}\text { Vertice Trescientos Sesenta Grados, } \\
\text { S.A }\end{array}$ & $\begin{array}{l}\text { Technology, media and } \\
\text { telecommunications }\end{array}$ & Negative working capital \\
\hline BDO & $\mathrm{CM}$ & Nyesa Valores Corporación, S.A & Construction and real estate & Equity below two thirds of social capital \\
\hline \multicolumn{5}{|c|}{ Block B: Going concern paragraphs included as a KAM } \\
\hline Deloitte & $\mathrm{CM}$ & Promotora de Informaciones, S.A & $\begin{array}{l}\text { Technology, media and } \\
\text { telecommunication }\end{array}$ & $\begin{array}{l}\text { Evolution of the patrimonial and financial } \\
\text { structure of the company }\end{array}$ \\
\hline PWC & $\mathrm{CM}$ & Pharma Mar, S.A & Services & Financial capability \\
\hline KPMG & $\mathrm{CM}$ & Ecolumber, S.A & $\begin{array}{l}\text { Energy and Natural } \\
\text { Resources }\end{array}$ & Financing of the activity of the group \\
\hline $\mathrm{BDO}$ & CM & Sniace, S.A & $\begin{array}{l}\text { Energy and Natural } \\
\text { Resources }\end{array}$ & Application of the going concern principle \\
\hline
\end{tabular}

Source: own elaboration based on the annual report of each company downloaded in CNMV webpage.

going concern issue is included among the other KAMs, this can obfuscate the impact of the firm's risks in relation to viability (Courtis, 1998; Merkl-Davies \& Brennan, 2007; Rutherford, 2003). If the going concern issue is not disclosed in the annual reports, this situation implies the need for a qualified opinion in the audit report. If the going concern issue is disclosed in the annual report, then the auditors should verify it. If the auditors agree, they should disclose it as a KAM, otherwise, for the emphasis it should be a separate paragraph to give more visibility for the users of financial information (see section 2, description of the new audit report).

\subsubsection{KAM analysis (Block $B$ and $C$ )}

\subsubsection{Number of risks}

While the standards provide guidelines for determining whether or not an audit matter constitutes a KAM, there is relatively little guidance on the number of KAMs that should be reported. Indeed, which and how many KAMs to report is a matter of professional judgment.

\section{- Number of risks reported by audit firms}

We have collected data on the number of risks reported by each audit firm in our sample. The average total number of risks reported for companies on the CM is between three and four while for those on Ibex-35 it is between two and three.

\section{- Number of risks by sector}

We have also analyzed the distribution of risks between different sectors (see Table 5).

Table 5

Number of risk by sector

\begin{tabular}{lcccccccc}
\hline \multirow{2}{*}{ Sector } & \multicolumn{2}{c}{ Ibex-35 } & \multicolumn{2}{c}{ CM } & \multicolumn{2}{c}{ Total } & \multicolumn{2}{c}{ Average } \\
& No. & No & No. & No. & No. & No. & Ibex-35 & CM \\
& Firms & Risks & Firms & Risks & Firms & Risks & & \\
\hline Construction \& real estate & 5 & 17 & 22 & 52 & 27 & 69 & 3.4 & 2.4 \\
Consumption \& distribution & 2 & 5 & 6 & 12 & 8 & 17 & 2.5 & 2.0 \\
Energy \& natural resources & 8 & 32 & 8 & 22 & 16 & 54 & 4.0 & 2.8 \\
Financial & 7 & 37 & 7 & 24 & 14 & 61 & 5.3 & 3.4 \\
Health & - & & 2 & 4 & 2 & 4 & & 2.0 \\
Industry & 4 & 12 & 26 & 67 & 30 & 79 & 3.0 & 2.6 \\
Services & 5 & 14 & 18 & 41 & 23 & 55 & 2.8 & 2.3 \\
Technology, media \& & 4 & 12 & 7 & 22 & 11 & 34 & 3.0 & 3.1 \\
telecommunications & 35 & 129 & 96 & 244 & 131 & 373 & & \\
Total & & & & & & &
\end{tabular}

Source: own elaboration based on the annual report of each company downloaded in CNMV webpage.

The financial sector is the one with the highest average number of risks for both IBEX-35 and CM companies. One possible explanation for this is the greater requirements in the new specific financial regulations and the new standards that have entered or will enter, into force in the next few years such as IFRS 15 (revenues) and 16 (leasing). Moreover, information systems are critical in this sector. This sector is followed by construction in IBEX-35 and Technology, Media 
and Telecommunications in CM.

\subsubsection{Risk Types}

As shown in Table 3, the majority of the KAMs identified for large companies in Spain relate to revenue recognition, impairment of goodwill and deferred tax recovery. This is perhaps unsurprising since these are often critical areas of judgment by management and of particular significance to the valuation of companies. These three highest-ranked risks comprise $41 \%$ of the total number of risks (373) reported by auditors in our study.

\subsubsection{Risk description granularity}

ISA 700 requires that "in order to be useful to users of the financial statements, the explanations of the matters required to be set out in the auditor's report shall be described [...] in a way that enables them to be related directly to the specific circumstances of the audited entity and are not, therefore, generic or abstract matters expressed in standardized language". We have evaluated the descriptions of the KAMs in each of the 131 auditor's reports in our study. An analysis of our evaluations by the firm shows that there are differences between the audit firms. For example, Deloitte seems to have provided the most granular non-standardized risk disclosures, with about $49 \%$ of the granular risks that cite specific circumstances. Excluding KPMG from the analysis would result in an approximate 40/60 split between granular and generic risk descriptions. This could be an indicator that there is room for improvement in terms of customizing the risk descriptions. In other words, the descriptions of KAMs for Spanish listed firms are very general and similar (around $65 \%$ of the total) from one audit report to other, diminishing the utility of disclosing risks.

\subsubsection{Conciseness}

Investors value information particularly highly when it is presented in a concise way. This creates a particular challenge for auditors since at the same time they are being asked to convey granular information about highly technical matters in a concise and easy to understand way. This, therefore, prompted us to review the volume of disclosure, as well as its content. We have analyzed the average word count for the risk descriptions in each report. The average word count for IBEX-35 companies is 440 and 394 for CM companies. On average, risk descriptions tend to be longer for IBEX-35 companies than for CM companies. This may be because they are generally larger and more complex businesses. In terms of the audit firms, PWC and EY tend to include longer risk descriptions in all their reports. This reflects the way in which those audit firms have sought to provide greater transparency and detail in the reporting of risks, but it also highlights the challenge of meeting potentially contradictory expectations among the users of the reports. Prior to the audit reform, auditors did not show these KAMs because they were part of the confidential information between the companies and the audit firms and were included in the management letters. Currently, this information is available for all readers and is also standardized.

\subsection{Analysis of the KAMs by structural factors}

Once the content of the audit reports of the listed companies in the sample had been classified, we carried out some statistical tests to answer the second research question (RQ2).
Therefore, in the next sections we analyze the relationship between the KAMs and the structural factors: (i) company sector, (ii) market type, (iii) auditor size, (iv) audit opinion, (v) the existence of emphasis paragraph, (vi) going concern paragraph and (vii) average word count per KAM. These have been considered as key factors in previous studies (Ahsan, 2013; Geiger \& Rama, 2006; Herbohn, Ragunathan, \& Garsden, 2007; Reynolds \& Francis, 2000). Although these factors have previously been studied separately, this paper is the first to examine these factors specifically in relation to KAMs and as a whole.

\subsubsection{Content of KAMs and sector}

In this section, a specific analysis of the content of the KAMs is performed taking into account the sector. As shown in Table 6, the type of risk disclosure by auditors in KAMs depends on the sector, since the p-value $(0.006)$ is lower than 0.05 in the three tests carried out. Dunn and Mayhew (2004) also report a positive association between industry-specialist audit firms and analysts' rankings of disclosure quality. This conclusion is in line with a previous study (Ruiz-Barbadillo, Gómez-Aguilar, \& Aguilar-Contreras, 2002) that shows that differences per sector are due to the nature of each sector that generates inherent risks that support the financial statements and impact on the quality of financial information. For instance, sectors intensive in capital, such as construction or energy, account for the main portfolio of risks on fixed assets, investment property and compliance with contractual terms due to the related agreements. In the case of the financial sector, it accounts for the majority of the risks related to legal and regulatory compliance, due to the new sector regulations and the new standards that have entered, or will enter, into force in the following years and the information systems that are critical in this sector. According to the KPMG (2018a) study, the Spanish banks have to implement more than 100 regulations in the period 2018-2020. The financial sector also represents $43 \%$ of the unusual or significant transactions because in 2017 a lot of mergers took place due to the financial regulations encouraging concentration in the Spanish banking market (i.e. acquisition of Banco Popular by Banco Santander, merger by absorption of Banco Mare Nostrum S.A by Bankia S.A, etc.).

Table 6

The content of KAMs and sector

\begin{tabular}{|c|c|c|c|c|c|c|c|c|c|}
\hline KAMs & C\&RE & CO\&D & E\&NR & $\mathbf{F}$ & $\mathrm{H}$ & I & $\mathrm{s}$ & TMT & Totals \\
\hline Fixed assets & 15 & 4 & 17 & 13 & 0 & 14 & 12 & 2 & 77 \\
\hline Current assets & 9 & 4 & 4 & 3 & 0 & 5 & 2 & 0 & 27 \\
\hline Liabilities & 9 & 1 & 9 & 13 & 0 & 10 & 10 & 4 & 56 \\
\hline Revenue recognition & 13 & 2 & 7 & 3 & 2 & 14 & 8 & 9 & 58 \\
\hline Goodwill and Business Combinations & 8 & 2 & 7 & 10 & 2 & 19 & 11 & 11 & 70 \\
\hline Taxes & 13 & 2 & 4 & 5 & 0 & 15 & 9 & 4 & 52 \\
\hline Legal and regulatory compliance & 1 & 0 & 1 & 5 & 0 & 1 & 1 & 1 & 10 \\
\hline Related party transactions & 1 & 1 & 2 & 3 & 0 & 0 & 0 & 1 & 8 \\
\hline Going concern & 0 & 0 & 2 & 0 & 0 & 0 & 1 & 1 & 4 \\
\hline Information systems & 0 & 1 & 1 & 6 & 0 & 1 & 1 & 1 & 11 \\
\hline Total & 69 & 17 & 54 & 61 & 4 & 79 & 55 & 34 & 373 \\
\hline $\mathrm{X}^{2}$ & 83.534 & & & & & & & & \\
\hline df & 54 & & & & & & & & \\
\hline p-value & 0.00 & & & & & & & & \\
\hline CHI simulated p-value & 0.0049 & & & & & & & & \\
\hline G-test & 0.0044 & & & & & & & & \\
\hline
\end{tabular}

Source: own elaboration.

Notes: C\&RE: Construction and Real Estate; CO\&D: Consumption and Distribution; E\&NR: Energy and Natural Resources; F: Financial; H: Health; I: Industry; S: Services; TMT: Technology, Media and Telco. 


\subsubsection{Content of KAMs and market type}

In this section, a specific analysis of the content of the KAMs is performed taking into account the market type. As shown in Table 7, the differences between KAMs and the market type are significant $(\mathrm{p}$-value $<0.05)$ for the three contingency tests. This means that the type of risk considered by auditors could depend on the market. The KAMs for which the IBEX-35 accounts for more than $50 \%$ of the total are information systems, legal and regulatory compliance, pensions, taxes, and unusual or significant transactions. This is consistent with the results of the previous section, as these are mainly related to the financial sector which has all of its companies listed on IBEX-35. In the case of pensions, these risks are concentrated in three IBEX-35 companies, namely Iberdrola, IAG and Banco Santander.

Table 7

The KAMS and type of market

\begin{tabular}{|c|c|c|c|}
\hline \multirow{2}{*}{ KAMs } & \multicolumn{2}{|c|}{ IBEX-35/CM } & \multirow[b]{2}{*}{ Total } \\
\hline & IBEX-35 & $\mathrm{CM}$ & \\
\hline Fixed assets & 27 & 50 & 77 \\
\hline Current assets & 4 & 23 & 27 \\
\hline Liabilities & 25 & 31 & 56 \\
\hline Revenue recognition & 16 & 42 & 58 \\
\hline Goodwill and Business Combinations & 25 & 45 & 70 \\
\hline Taxes & 16 & 36 & 52 \\
\hline Legal and regulatory compliance & 4 & 6 & 10 \\
\hline Related party transactions & 4 & 4 & 8 \\
\hline Going concern & 0 & 4 & 4 \\
\hline Information systems & 8 & 3 & 11 \\
\hline Total & 129 & 244 & 373 \\
\hline $\mathrm{X}^{2}$ & 18.965 & & \\
\hline df & 9 & & \\
\hline p-value & 0.02549 & & \\
\hline CHI simulated $p$-value & 0.01949 & & \\
\hline G-test & 0.01542 & & \\
\hline
\end{tabular}

Source: own elaboration.

\subsubsection{Content of KAMs and auditor size}

In this section, a specific analysis of the content of KAMs is performed taking into account the size of the auditor. As shown in Table 8, the big four audit firms include more accounting and general KAMs than the rest. In particular, KAMs identified by the Big Four represent $93 \%$ of the total, in line with their market share of around $90 \%$.

However, the p-value $(0.1376>0.05)$ is not significant, which means that we have not found that auditor size has an influence on KAMs. This could be due to the fact that nonbig four auditors want to protect themselves against potential liabilities by properly describing the KAMs in their audit reports, including how these were addressed in the audit. This could also imply a possible positive effect on the quality of audits to ensure that the procedures are sufficient to mitigate the need to report on these KAMs. This hypothesis is in line with prior studies that suggest that the association between auditor size and audit quality depends on the country's litigation risks (Choi, Kim, Liu, \& Simunic, 2008; Francis \& Wang, 2008; Wong, Firth, \& Lo, 2018).
Table 8

The KAMs and the size of the auditor

\begin{tabular}{lccc}
\hline \multicolumn{1}{c}{ KAMs } & Big Four & Non-Big Four & Total \\
\hline Fixed assets & 68 & 9 & 77 \\
Current assets & 24 & 3 & 27 \\
Liabilities & 50 & 6 & 56 \\
Revenue Recognition & 57 & 1 & 58 \\
Goodwill and business combination & 68 & 2 & 70 \\
Taxes & 49 & 3 & 52 \\
Legal and regulatory compliance & 10 & 0 & 10 \\
Related party transactions & 8 & 0 & 8 \\
Going concern & 3 & 1 & 4 \\
Information systems & 11 & 0 & 11 \\
\hline \multicolumn{1}{c}{ Total } & $\mathbf{3 4 8}$ & $\mathbf{2 5}$ & $\mathbf{3 7 3}$ \\
\hline \multicolumn{1}{c}{ df } & $\mathbf{1 3 . 5 9 3}$ & & \\
\multicolumn{1}{c}{ p-value } & $\mathbf{9}$ & & \\
\multicolumn{1}{c}{ G-test } & $\mathbf{0 . 1 3 7 6}$ & & \\
\hline
\end{tabular}

Source: own elaboration.

\subsubsection{Content of KAMs and audit opinion}

In this section, a specific analysis of the content of the KAMs is performed taking into account the audit opinion. As shown in Table 9, the differences between KAMs and audit opinion are not significant ( $\mathrm{p}$-value $>0.05$ ). This means that audit opinion and KAMs are not directly associated. This is because a KAM is one that has been important in the course of the audit work and has required significant attention from the auditor, due to its complexity, the serious professional judgment of the auditor, etc. If these issues are resolved satisfactorily, they will be a KAM. If there is no satisfactory answer, they will not appear as such and there will be a qualified opinion for the auditor's report. Therefore, the number of KAMs is not directly related to the type of opinion issued by the auditor on whether the annual accounts express a true image of the company's reality.

Table 9

The KAMs and audit opinion

\begin{tabular}{|c|c|c|c|}
\hline \multirow{2}{*}{ KAMs } & \multicolumn{2}{|c|}{ Unqualified/Qualified } & \multirow{2}{*}{ Tota } \\
\hline & Unqualified & Qualified & \\
\hline Fixed assets & 76 & 1 & 77 \\
\hline Current assets & 27 & 0 & 27 \\
\hline Liabilities & 52 & 4 & 56 \\
\hline Revenue recognition & 58 & 0 & 58 \\
\hline Goodwill and Business Combinations & 68 & 2 & 70 \\
\hline Taxes & 52 & 0 & 52 \\
\hline Legal and regulatory compliance & 10 & 0 & 10 \\
\hline Related party transactions & 8 & 0 & 8 \\
\hline Going concern & 4 & 0 & 4 \\
\hline Information systems & 11 & 0 & 11 \\
\hline Total & 366 & 7 & 373 \\
\hline $\mathrm{X}^{2}$ & 19.12 & & \\
\hline df & 9 & & \\
\hline p-value & 0.2028 & & \\
\hline CHI simulated $p$-value & 0.2029 & & \\
\hline G-test & 0.2208 & & \\
\hline
\end{tabular}

Source: own elaboration.

This fact is in line with the new structure of the audit report which separates the audit opinion paragraph from the KAMs disclosed to clearly highlight which is an issue for the auditor 
in terms of a qualified opinion, and which are potential areas of risks and awareness (KAMs) where the auditor must explain the procedures performed to address them. This could be because although a company had an unqualified opinion, the auditor must describe the KAMs in the extended audit report in accordance with ISA 701 Communicating Key Audit Matters in the Independent Auditor's Report.

\subsubsection{Content of KAMs and emphasis and going concern paragraphs}

In this section, a specific analysis of the content of the KAMs is performed taking into account the emphasis and going concern paragraphs. As shown in Table 10, the differences between KAMs and these factors are not significant (p-value $>0.05$ ). This means that the type of risk considered by auditors does not depend on these factors. That could be because the going concern paragraph refers to a material uncertainty related to the entity's ability to continue as a going concern while KAMs are areas of higher risk of material misstatement or significant risks but that does not necessarily mean that they have an impact on the issue of going concern. With the new ISA 701, the going concern issue is highlighted in a specific section over and above the disclosure of KAMs, so the auditor is not conditioned by the going concern issue to disclose KAMs. In line with this explanation, the emphasis paragraph highlights some information that is already included in the annual accounts so it makes no sense to also describe it in the KAMs.

Table 10

The KAMs, emphasis paragraph and going concern

\begin{tabular}{|c|c|c|c|c|c|c|}
\hline \multirow{2}{*}{ KAMs } & \multicolumn{3}{|c|}{ Emphasis paragraph } & \multicolumn{3}{|c|}{ Going concern } \\
\hline & NO & YES & Total & NO & YES & Total \\
\hline Fixed assets & 75 & 2 & 77 & 70 & 7 & 77 \\
\hline Current assets & 26 & 1 & 27 & 24 & 3 & 27 \\
\hline Liabilities & 51 & 5 & 56 & 47 & 9 & 56 \\
\hline Revenue recognition & 56 & 2 & 58 & 54 & 4 & 58 \\
\hline Goodwill and Business Combinations & 68 & 2 & 70 & 67 & 3 & 70 \\
\hline Taxes & 50 & 2 & 52 & 49 & 3 & 52 \\
\hline Legal and regulatory compliance & 9 & 1 & 10 & 10 & 0 & 10 \\
\hline Related party transactions & 4 & 0 & 4 & 4 & 0 & 4 \\
\hline Going concern & 7 & 1 & 8 & 8 & 0 & 8 \\
\hline Information systems & 10 & 1 & 11 & 11 & 0 & 11 \\
\hline Total & 356 & 17 & 373 & 344 & 29 & 373 \\
\hline $\mathrm{X}^{2}$ & 6.4267 & & & 10.306 & & \\
\hline df & 9 & & & 9 & & \\
\hline p-value & 0.6966 & & & 0.3263 & & \\
\hline CHI simulated $p$-value & 0.6677 & & & 0.3008 & & \\
\hline G-test & 0.7729 & & & 0.2197 & & \\
\hline
\end{tabular}

Source: own elaboration.

\subsubsection{Content of KAMs and average word count per KAM}

As mentioned above, the number of words in a report could hide information relevant to stakeholders. For example, the litigation risks to which auditors are exposed could encourage companies to write longer reports (Aerts \& Yan, 2017; Bloomfield, 2008). Due to average word count is a continuous variable, the Kruskal-Wallis test was run (untabulated). The p-value was $0.6023>0.05$ so there may be no significant relationship between the KAMs and the average word count per KAM. This could be due to the standardization of the content of the KAMs that do not include specific issues.

Additionally, Table 11 shows that the average word count per KAM is quite similar for all of the KAMs, which could suggest that there are very standardized descriptions of each KAM.
Table 11

Word account per KAM

\begin{tabular}{lcccc}
\hline \multicolumn{1}{c}{ KAMs } & \multicolumn{4}{c}{ Word account } \\
& Average & Maximum & Minimum & Std \\
\hline Fixed assets & 448 & 1.198 & 193 & 195 \\
Current assets & 403 & 707 & 249 & 110 \\
Liabilities & 394 & 723 & 146 & 141 \\
Revenue recognition & 390 & 662 & 192 & 110 \\
Goodwill and business combinations & 427 & 924 & 116 & 161 \\
Taxes & 376 & 702 & 136 & 120 \\
Legal and regulatory compliance & 422 & 583 & 366 & 139 \\
Related party transactions & 406 & 456 & 206 & 45 \\
Going concern & 467 & 829 & 243 & 179 \\
Information systems & 401 & 552 & 116 & 102 \\
\hline Total & 410 & 1.198 & 116 & 148
\end{tabular}

\subsubsection{Multinomial regression model}

Finally, we ran a multinomial regression to test the model that could explain the different KAMs in relation to the seven independent variables considered. As we can see in Table 12 , the model proposed is significant as its significance level is 0.000 and the variables that explain the KAMs are sector, market type, and average word count, all of them with pvalues lower than 0.05 . Other untabulated validity measures of our model confirm our results, being 1339.59 and chi-squared $=16.464, \mathrm{df}=36$, sig. $=0.9978$ respectively, the $2 \log (\mathrm{L})$ and Hosmer \& Leme show tests.

Table 12

The model of KAMs and structural factors

\begin{tabular}{lccc}
\hline \multicolumn{1}{c}{ STRUCTURAL FACTORS } & \multicolumn{1}{c}{$\mathrm{X}^{2}$} & $\mathrm{df}$ & $\mathrm{p}$-value \\
\hline Sector & $\mathbf{8 6 . 1 4 6}$ & $\mathbf{5 4}$ & $\mathbf{0 . 0 0 3 5 4}$ \\
Type of market & $\mathbf{2 0 . 1 5 9}$ & 9 & $\mathbf{0 . 0 1 6 9 6}$ \\
Size of auditor & 11.014 & 9 & 0.27475 \\
Type of opinion & 11.438 & 9 & 0.24687 \\
Emphasis paragraph & 5.147 & 9 & 0.82127 \\
Going concern & 8.241 & 9 & 0.51004 \\
Average word count & $\mathbf{1 8 . 0 0 4}$ & $\mathbf{9}$ & $\mathbf{0 . 0 3 5 1 2}$ \\
\hline Chi-squared & $\mathbf{1 6 0 . 2 4 7 6}$ & & \\
df & $\mathbf{1 0 8}$ & & \\
Sig. & $\mathbf{0 . 0 0 0 8 2 3 8}$ & & \\
\hline
\end{tabular}

Notes: In bold, the significant variables are considered at $5 \%$ level significance. Source: own elaboration.

The results show that the sector, market type, and average word count variables remain significant in explaining the KAMs, alone or with other variables. The different significance of some variables when comparing correlation tests is due to the fact that the individual effects between the dependent and each independent variable could be different to the global effect between the dependent and all independent variables are taken together (Novales, 2010). This could be due to the fact that companies in the same sector are subject to similar inherent risks that have an impact on the financial statements (Ruiz-Barbadillo et al., 2002). The market type is also significant as IBEX-35 listed companies are in the spotlight of the regulator (CNMV) and have more impact on the media in terms of reputation and visibility. The average word count per KAM is also significant for the model of KAMs. This result is in line with impression management theory that posits that the use of more words could hide bad news (Li, 2008; Rutherford, 2003). In other words, the longer the explanation of a KAM, the higher the probability that it is hiding bad news. This is also consistent with the management obfuscation hypothesis that states that complex narratives are less effective and, therefore, capital market participants de- 
mand more understandable and useful information for decision making (De Souza, Rissatti, Rover, \& Borba, 2019).

\section{Conclusions}

After the financial crisis and due to the growing complexity of financial reporting, investors and other financial statement users have demanded more informative auditor's reports. The auditing profession has had to respond to investors around the world who expressed their dissatisfaction with auditor's reports. A simple 'true and fair' opinion was no longer enough and they demanded more informative reports. This is called the "audit expectation gap" and it has been extensively analyzed in the existing literature, promoting the role of the new standards to achieve more effective financial reporting for the decision-making processes of its users.

In this context, the IAASB, aware of the need for a change in the focus of audit reports, approved a new international standard that incorporates major changes in the information contained in audit reports. One of the major changes is the obligation for listed companies to include KAMs in the audit report. In the European Union, the IAASB regulatory framework has been adopted through Directive 2014/56/EU and Regulation No. 537/2014, being enforced in Spain through Law 22/2015 on Account Auditing (LAC) for the financial years commencing after June 17, 2016.

This paper empirically analyses the content of the new audit reports after the accounting reform recently carried out in Spain and the factors that condition the KAMs disclosed by auditors. Our findings show that the new audit reports are adding more transparency in terms of the audit and the real economic and financial situation of companies, in line with the KPMG (2018b) report. As the Spanish experience of this reporting affects the largest companies, qualified opinions and emphases of matter are rare. Additionally, the going concern section relates to companies with a qualified opinion. It is also remarkable that some auditors consider a going concern to be a KAM but not in a specific section. This is an important issue to analyze in depth because some firms could hide some financial distress risks by treating them as a KAM instead of disclosing them in a separate section.

While the standards provide guidelines for determining whether an audit matter constitutes a KAM, there is relatively little guidance on the number of KAMs that should be reported, this being a matter of professional judgment. Large companies in Spain mostly report two to four KAMs and most of these relate to revenue recognition, impairment of goodwill and deferred tax recovery. These three highest-ranked risks account for 152 instances of reported risks and $41 \%$ of the total number of risks reported by auditors in our study. In particular, the average total number of risks reported for companies on the CM is slightly higher than those for companies on Ibex-35. Moreover, the financial sector is the one with the highest average number of risks, followed by construction and technology, media and telecommunications. Additionally, most KAMs are largely generic in nature, using more standardized language. This issue highlights the challenge of meeting potentially contradictory expectations from the users of such reports.

In terms of the structural factors, the significant variables that explain the KAMs in our sample are sector, market type, and average word count. It is possible to have different KAMs depending on these three variables, which is something that firms' stakeholders should be aware of when reading the new extended audit report. Neither auditor size nor type of opinion, for example, have an impact on KAM.
Our study aims to expand the literature by examining the value of audit reports and to inform ongoing regulatory action. For instance, auditors in the US will start issuing extended reports in 2019, including a discussion of critical audit matters (CAMs). We hope that our study will stimulate discussion of possible additional mechanisms for improving the content of audit reports in Spain and other countries. Future contributions could also focus on qualitative research based on the perceptions of stakeholders about the information in the new audit report.

Finally, this study is not free from limitations. The research is based on only one year. Data from a longer period should be analyzed when new audit reports become available. Our sample is focused on listed firms and listed companies do not have the same behavior as private firms so future research could include a comparison between new audit reports in private and public firms. The impact of this new regulation on financial markets and the firm's valuation could also be relevant to analyze.

\section{Funding}

This research did not receive any specific grant from funding agencies in the public, commercial or not-for-profit sectors.

\section{Conflict of interests}

The authors declare no conflict of interests.

\section{References}

Abad, D., Sánchez-Ballesta, J.P., \& Yagüe, J. (2017). Audit opinions and information asymmetry in the stock market. Accounting and Finance, 57(2), 565-595. https://doi.org/10. 1111/acfi.12175

Adeyemi, S., \& Marte Uadiale, O. (2011). An empirical investigation of the audit expectation gap in Nigeria. African Journal of Business Management, 5(19), 7964-7971. doi:10. 5897/AJBM11.1671

Aerts, W., \& Yan, B. (2017). Rhetorical impression management in the letter to shareholders and institutional setting: A metadiscourse perspective. Accounting', Auditing and Accountability Journal, 30(2), 404-432. doi:10.1108/ AAAJ-01-2015-1916

Ahsan, H. (2013). A metaanalysis of the determinants of modified audit opinion decisions. Managerial Auditing Journal, 28(3), 184-216 https://doi.org/10.1108/ 02686901311304349

Bloomfield, R. (2008). Discussion of "Annual report readability, current earnings, and earnings persistence". Journal of Accounting and Economics, 2(3), 248-252. https://doi.org/ 10.1016/j.jacceco.2008.04.002

Boone, J., Khurana, I., \& Raman, K. (2010). Do the big 4 and the second-tier firms provide audits of similar quality? Journal of Accounting and Public Policy, 29(4), 330-330. doi: 10.1016/j.jaccpubpol.2010.06.007.

Boolaky, P.K., \& Quick, R. (2016). Bank Directors' Perceptions of Expanded Auditor's Reports. International Journal of Auditing, 20(1), 158-174. https://doi.org/10.1111/ijau. 12063

Brasel, K., Doxey, M., Grenier, J.H., \& Reffett, A. (2016). Risk Disclosure Preceding Negative Outcomes: The Effects of Reporting Critical Audit Matters on Judgments of Auditor 
Liability. Accounting Review, 91(5), 1345-1362. https://doi. org/10.2139/ssrn.2487396

Butler, M., Leone, A.J., \& Willenborg, M. (2004). An empirical analysis of auditor reporting and its association with abnormal accruals. Journal of Accounting and Economics, 2, 139-135. https://doi.org/10.2139/ssrn.298700

Carson, E., Fargher, N., Geiger, M.A., Lennox, C.S., Raghunandan, K., \& Willekens, M. (2013). Audit Reporting for Going-Concern Uncertainty: A Research Synthesis. Auditing-A Journal of Practice and Theory, 32, 353-384. https: //doi.org/10.2308/ajpt-50324

Choi, J. H., Kim, J. B., Liu, X., \& Simunic, D. A. (2008). Audit pricing, legal liability regimes, and Big 4 premiums: Theory and crosscountry evidence. Contemporary Accounting Research, 25(1), 55-99. https://doi.org/10.1506/car.25.1.2

Christensen, B. E., Glover, S.M., \& Wood, D.A (2012). Extreme Estimation Uncertainty in Fair Value Estimates: Implications for Audit Assurance. Auditing-A Journal of Practice and Theory, 31(1), 127-146. https://doi.org/10.2308/ ajpt-10191

Chye Koh, H., \& Woo, E. S. (1998). The expectation gap in auditing. Managerial Auditing Journal, 13(3), 147154.https://doi.org/10.1108/02686909810208038

Clive S., Schmidt, J., \& Thompson, A. (2019). Is the expanded model of audit reporting informative to investors? Evidence from the UK. Journal of Accounting and Economics, 3-53 (forthcoming). https://doi.org/10.2139/ssrn.2619785

Coram, P.J., Mock, T.J., Turner, J.L., \& Gray, G.L. (2011). The Communicative Value of the Auditor's Report. Australian Accounting Review, 21(3), 235- 252. https://doi.org/10. 1111/j.1835-2561.2011.00140.x

Courtis, J. K. (1998). Annual report readability variability: tests of the obfuscation hypothesis. Accounting, Auditing \& Accountability Journal, 11(4), 459-472. https://doi.org/10. 1108/09513579810231457

Cox, J.D. (2013). Strengthening Financial Reporting: An Essay on Expanding the Auditor's Opinion Letter. George Washington Law Review, 81(3), 1036-1062. Available at: https://scholarship.law.duke.edu/faculty/ scholarship/ 2869

Czerney, K., Schmidt, J.J., \& Thompson, A.M. (2014). Does Auditor Explanatory Language in Unqualified Audit Reports Indicate Increased Financial Misstatement Risk?. The Accounting Review, 89(6), 2115-2149. https://doi.org/10. 2308/accr-50836

De Souza, J., Rissatti, J., Rover, S., \& Borba, J.A. (2019). The linguistic complexities of narrative accounting disclosure on financial statements: An analysis based on readability characteristics. Research in International Business and Finance, 48(C), 59-74. https://doi.org/10.1016/j.ribaf.2018. 12.008

Dunn, K. A., \& Mayhew, B. W. (2004). Audit firm industry specialization and client disclosure quality. Review of Accounting Studies, 9(1), 35-58. https://doi.org/10.1023/B: RAST.0000013628.49401.69

Fakhfakh, M. (2016a). Linguistic features and legibility of the consolidated audit reports: An original investigation from the Tunisian case. Cogent Business and Management, 3, 655-687. https://doi.org/10.1080/23311975. 2016.1234360.

Fakhfakh, M. (2016b). The readability of international illustration of auditor's report: An advanced reflection on the compromise between normative principles and linguistic requirements. Journal of Economics, Finance and Administrative Science, 20(38), 21-29. https://doi.org/10.1016/j.jefas.

\subsection{2 .001$.}

Francis, J.R., \& Wang, D. (2008). The joint effect of investor protection and Big 4 audits on earnings quality around the world. Contemporary Accounting Research, 25(1), 157191.https://doi.org/10.1506/car.25.1.6

Gambetta, N., Orta Pérez, M., Sierra Garcia, L., \& García Benau, M. A. (2019). Las cuestiones clave de auditoría esperadas en España: £son los auditores previsibles?. Revista De Contabilidad - Spanish Accounting Review, 22(1), 32-40. https://doi.org/10.6018/rc-sar.22.1.354291

Gassen, J., \& Skaife, H. (2009).Can Audit Reforms Affect the Information Role of Audits? Evidence from the German Market. Contemporary Accounting Research, 26 (3), 867-882. https://doi.org/10.2139/ssrn.933010

Geiger, M. A., \& Rama, D. V. (2006). Audit firm size and going-concern reporting accuracy. Accounting Horizons, 20(1), 1-17. doi:10.2308/acch.2006.20.1.1

Gold, A., Gronewold, U., \& Pott, C. (2012). The ISA 700 auditor's report and the audit expectation gap-do explanations matter?. International Journal of Auditing, 16(3), 286307. https://doi.org/10.1111/j.1099-1123.2012.00452.x

Gonzalo Angulo, J.A., \& Garvey, A. M. (2018). Investigar en auditoría: algunas reflexiones. Revista De Contabilidad Spanish Accounting Review, 21(2), 107-115. https://doi.org/ 10.1016/j.rcsar.2018.05.004

Gray, G.L., Turner, J.L., Coram, P.J., \& Mock, T.J. (2011). Perceptions and Misperceptions Regarding the Unqualified Auditor's Report by Financial Statement Preparers, Users, and Auditors. Accounting Horizons, 25(4), 659-684. https: //doi.org/10.2308/acch-50060.

Guiral-Contreras, A., Gonzalo-Angulo, J.A., \& Rodgers, W. (2007). Information content and recently effect of the audit report in loan rating decisions. Accounting and Finance, 47(2), 285-304. doi:10.1111/j.1467629x.2006.00208.x

Gutierrez, E., Minutti-Meza, M., Tatum, K., \& Vulcheva, M. (2017). Consequences of adopting an expanded auditor's report in the United Kingdom. Journal of Accounting and Economics, 1-61.https://doi.org/10.2139/ssrn.2741174

Hategan, C., Ioana, J., Renata Dana, N., Nicoleta, S., \& Iacobuta, A. (2015). The relevance of communication through independent auditor's report to the European business environment. Comparative study of Romania and Spain. Transformations in Business and Economics, 14 (2A), 378-392.

Herbohn, K., Ragunathan, V., \& Garsden, R. (2007). The horse has bolted: revisiting the market reaction to going concern modifications of audit reports. Accounting and Finance, 47 (3), 473-493. https://doi.org/10.1111/j. 1467-629x.2007.00216.x.

IAASB (2015). The new auditor's report: enhancing auditor communications. Greater Transparency into the Financial Statement Audit. Available at: https://www.ifac.org/system/ files/uploads/IAASB/Auditor-Reporting-Fact-Sheet.pdf

IAASB (2016). More Informative Auditor's Reports - What Audit Committees and Finance Executives Need to Know. Available at: https://www.ifac.org/publications\%2Dresources/ more\%2Dinformative\%2Dauditors\%2Dreports\%2Dwhat\% 2Daudit\%2Dcommittees\%2Dand\%2Dfinance

ICAC (2017). *Situación de la Auditoría en España. Available at: http://www.icac.meh.es/Documentos/INFORMES/ 01.Situaci\%C3\%B3n\%20de\%20la\%20Auditor\%C3\%ADa\% 20en\%20Espa\%C3\%B1a/06.A\%C3\%B1o\%202017.pdf

IFAC (2013). Reporting on Audited Financial Statements: Proposed New and Revised International Standards on Auditing. Exposure Draft. Available at: https://www.ifac.org/system/files/publications/files/ 


\section{All\%20Proposed\%20ISAs\%20Included\%20in\%20ED.pdf}

KPMG (2016). Nuevo informe de auditoría: mayor transparencia e información más relevante New audit report: more transparency and more relevant information. Available at: https://assets.kpmg.com/content/dam/kpmg/pdf/ 2016/03/nuevo-informe-auditoria.pdf

KPMG (2017). Key Audit Matters: Auditor's report snapshot 28 March $2017 . \quad$ Available at: https://home.kpmg.com/au/en/home/insights/2017/

03/key-audit-matters-auditor-report-28-march-2017.html

KPMG (2018a). Claves de la regulación financiera: impacto y horizonte para las entidades de crédito. Julio 2018 Keys to financial regulation: impact and horizon for credit institutions. July 2018. Available at: https://assets.kpmg.com/content/dam/kpmg/es/pdf/ 2018/07/claves-de-regulacion-financiera.pdf

KPMG (2018b). Cuestiones clave en los nuevos informes de auditoría. Lecciones de la experiencia en 2017-2018. Junio 2018. Keys in the new audit reports. Lessons from the experience. June 2018 Available at: https://home.kpmg.com/es/es/home/tendencias/ 2018/06/cuestiones-clave-nuevos-informes-auditoria.html

Lennox, C., Wu, X., \& Zhang, T. (2015). The effect of audit adjustments on earnings quality: Evidence from China. Journal of Accounting and Economics, 61 (2-3), 545-562. https://doi.org/10.1016/j.jacceco.2015.08.003

Li, F. (2008). Annual report readability, current earnings, and earnings persistence. Journal of Accounting and Economics, 45(2/3), 221-247. doi:10.1016/j.jacceco.2008.02.003

Litjens, R., Buuren, J., \& Vergoossen, R. (2015), Addressing Information Needs to Reduce the Audit Expectation Gap: Evidence from Dutch Bankers, Audited Companies and Auditors. International Journal of Auditing, 19, 267-281. doi: \%5B\%5B10.1111/ijau.12042\%5D\%7B.underline\%7D]

Martínez-Blasco, M., Vivas-Crisol, L., \& Garcia-Blandon, J. (2019). El informe de auditoría con salvedades: funa mayor independencia y competencia del auditor aumenta su contenido informativo?. Revista De Contabilidad - Spanish Accounting Review, 19(1), 89-101. https://doi.org/10.1016/j.rcsar. 2015.01.005

Masoud, N. (2017). An empirical study of audit expectation-performance gap: The case of Libya. Research in International Business and Finance, 41, 1-15. Doi:10.1016/j. ribaf.2017.04.012

Merkl-Davies, D.M., \& Brennan, N.M. (2007). Discretionary disclosure strategies in corporate narratives: incremental information or impression management?. Journal of Accounting Literature, 26, 116-196.

Mock, T.J., Gray, G.L., Coram, P.J., \& Turner, J.L. (2009). Perceptions and Misperceptions Regarding the Unqualified Auditor's Report by Financial Statement Preparers, Users, and Auditors. Accounting Horizons, 25 (4), 659-684. https: //doi.org/10.2308/acch-50060

Muñoz-Izquierdo, N., Camacho-Miñano, M.M., \& PascualEzama, D. (2017). Contenido del informe de auditoría en el año previo a la declaración del concurso de acreedores. Contraste empírico para el caso español. Spanish Journal of Finance and Accounting/Revista Española de Financiación y Contabilidad, 46(1), 92-126. https://doi.org/10.1080/ 02102412.2016.1245886

Novales, A. (2010). Análisis de regresión Regression analysis. Available at: https://www.ucm.es/data/cont/docs/ 518-2013-11-13-Analisis\%20de\%20Regresion.pdf

PCAOB (2013). Release No. 2013-005 August 13, 2013 PCAOB Rulemaking Docket Matter No. 034. Available at: https://pcaobus.org/Rulemaking/Docket034/Release/

\section{3-005/ ARM.pdf}

Porter, B. (1993) An empirical study of the audit expectation-performance gap. Accounting and Business Research, 24, Winter, 4968.https://doi.org/10.1080/00014788.1993.9729463

Prasad, P., \& Chand, P. (2017). The Changing Face of the Auditor's Report: Implications for Suppliers and Users of Financial Statements. Australian Accounting Review, 27 (4), 348367.https://doi.org/10.1111/auar.12137

PWC (2019). The Future of Audit: A framework for debate. Available at: https://www.pwc.co.uk/who-we-are/ future-of-audit/future-of-audit-report.pdf

Ruhnke, K., \& Schmidt, M. (2014). The audit expectation gap: existence,causes, and the impact of changes, Accounting and Business Research, 44(5), 572-601. doi:10.1080/ 00014788.2014.929519

Quick, R., \& Schmidt, F. (2018). Do audit firm rotation, auditor retention, and joint audits matter?-An experimental investigation of bank directors' and institutional investors' perceptions. Journal of Accounting Literature, 41, 121.https://doi.org/10.1016/j.acclit.2018.01.003

Ratzinger-Sakel, N. V., \& Gray, G. L. (2015). Moving toward a learned profession and purposeful integration: Quantifying the gap between the academic and practice communities in auditing and identifying new research opportunities. Journal of Accounting Literature, 35, 77-103. https://doi. org/10.1111/jifm.12095

Reynolds, J. K., \& Francis, J. R. (2000). Does size matter? The influence of large clients on office-level auditor reporting decisions. Journal of Accounting and Economics, 30(3), 375400. https://doi.org/10.1016/S0165-4101(01)00010-6

Ruiz Barbadillo, E. (1998). Dimensiones Informativas y Objetivos del Informe de Auditoria. Revista De Contabilidad - Spanish Accounting Review, 1(2), 129-152. Recuperado a partir de https://revistas.um.es/rcsar/article/view/384661.

Ruiz-Barbadillo, E., Gómez-Aguilar, N., \& AguilarContreras, G. (2002). Una comparación intersectorial y por tamaño de la calidad de la información contable a través del análisis del informe de auditoría A cross-sector comparison and size comparison of the quality of accounting information through the analysis of the audit report. Spanish Journal of Finance and Accounting/Revista Española de Financiación y Contabilidad, 31(112), 545-581. doi:10.1080/02102412. 2002.10779457

Ruiz Barbadillo, E., Rodríguez Castro, P. I., \& Biedma López, E. (2016). Barreras de entrada, concentración y competitividad en el mercado de auditoría español. Spanish Journal of Finance and Accounting/Revista Española de Financiación y Contabilidad, 45(1), 92-133. https://doi.org/10. 1080/02102412.2015.1092232

Rutherford, B.A. (2003). Obfuscation, textual complexity and the role of regulated narrative accounting disclosure in corporate governance. Journal of Management and Governance, 7(2), 187-210. https://doi.org/10.1023/A: 1023647615279.

Salehi, M. (2011). Audit expectation gap: Concept, nature and trace. Journal of Management and Governance, 7(2), 187210. https://doi.org/10.1023/A:1023647615279.

Samsonova-Taddei, A., \& Humphrey, C. (2015). Risk and the construction of a European audit policy agenda: The case of auditor liability. Accounting, Organizations and Society, 41, 55-72. https://doi.org/10.1016/j.aos.2014.08.002

Sikka, P. (2009). Financial crisis and the silence of the auditors. Accounting, Organizations and Society, 34(6-7), 868873. https://doi.org/10.1016/j.aos.2009.01.004

Sirois, L. P., Bédard, J., \& Bera, P. (2018). The informa- 
tional value of key audit matters in the auditor's report: Evidence from an eye-tracking study. Accounting Horizons, 32(2), 141-162.

Steven J. K., Schmith, J.J., \& Valentine, K. (2017). The Disclaimer Effect of Disclosing Critical Audit Matters in the Auditor's Report. Journal of Accounting and Economics, 1-48. https://doi.org/10.2139/ssrn.2481284

Tahinakis, P., \& Samarinas, M. (2016). The incremental information content of audit opinion. Journal of Applied Accounting Research, 17(2), 139-169. https://doi.org/10. 1108/JAAR-01-2013-0011

Tranfield, D., Denyer, D., \& Smart, P. (2003). Towards a methodology for developing evidence-informed management knowledge by means of systematic review. British Journal of Management, 14(3), 207-222.

Toumeh, A., Yahya, S., \& Walid Z.. (2018). Expectations gap between auditors and user of financial statements in the audit process. Asia-Pacific Management Accounting Journal, 13(3),79-107.Available at: http://arionline.uitm. edu.my/ojs/index.php/APMAJ/article/view/86

Vanstraelen, A., Schelleman, C., Meuwissen, R., \& Hofmann, I. (2012). The audit reporting debate: Seemingly intractable problems and feasible solutions. European Accounting Review, 21(2), 193-215. https://doi.org/10.1080/ 09638180.2012 .687506

Wong, R.M.K., Firth, M.A., \& Lo, A.W.Y. (2018). The impact of litigation risk on the association between audit quality and auditor size: Evidence from China. Journal of International Financial Management \& Accounting, 29(3), 280-311. https://doi.org/10.1111/jifm.12082.

Zenzerovic, R., \& Valic-Vale, M. (2016). Diagnosing companies in financial difficulty based on the auditor's report. Croatian Operational Research Review, 7(1), 147-158. doi: 10.17535/crorr.2016.0010 